\title{
Evaluation of In Vitro Antidiabetic and Antioxidant Activities and Preliminary Phytochemical Screening of Leaf Extracts of Avicennia officinalis
}

\author{
Swagat Kumar Das ${ }^{1}$, Dibyajyoti Samantaray ${ }^{1}$ and Hrudayanath Thatoi ${ }^{2 *}$ \\ ${ }^{1}$ Department of Biotechnology, College of Engineering and Technology, Biju Patnaik University of Technology, Odisha, India \\ ${ }^{2}$ Department of Biotechnology, North Orissa University, Odisha, India
}

\begin{abstract}
Avicennia officinalis is a medicinal mangrove plant and used in traditional folk medicine for treatment of various ailments. In the present study, the antidiabetic and antioxidant activities of petroleum ether and aqueous extracts of leaves of $A$. officinalis were evaluated. The antidiabetic activity was evaluated out by a-amylase and a-glucosidase inhibition study and antioxidant capacity by $\mathrm{DPPH}$, superoxide and hydrogen peroxide scavenging activity of leaf extracts at various concentrations. The maximum antidiabetic activity was observed in $1.0 \mathrm{mg} / \mathrm{ml}$ of leaves extract of aqueous extracts. The maximum superoxide and hydrogen peroxide scavenging activity were exhibited by aqueous extracts with $\mathrm{IC}_{50}$ values of 0.27 and $0.17 \mathrm{mg} / \mathrm{ml}$ respectively and maximum DPPH scavenging activity was shown by petroleum ether extracts with $\mathrm{IC}_{50}$ value of $0.25 \mathrm{mg} / \mathrm{ml}$. The qualitative and quantitative phytochemical analysis also showed presence of different phytochemicals including phenols, flavonoids and tannins which may be attributed to their antidiabetic and antioxidant activities. Thus, the present study gives a clear evidence that leaf extracts of $A$. officinalis possess both antidiabetic and antioxidant activities.
\end{abstract}

Keywords: Avicennia officinalis; In vitro; Antidiabetic; Antioxidant; Phytochemicals

\section{Introduction}

Mangroves are the halophytes plants living between interface of sea and land. The mangroves are known as the stress tolerant plant as they can thrive in ecological inhospitable conditions exemplified by high salinity, heavy metal, low oxygen, flooding, UV-B, water logging where no other plants can survive [1]. To survive under these stressful conditions, these unique plants are reported to be enriched with unique and diversified class of phytochemicals. The ethnomedicinal uses of these plants for treatment of various ailments may be attributed to the presence of these phytochemicals.

Amongst the different mangrove species, Avicennia officinalis L. is an important mangrove species belonging to family Acanthaceae [2]. The stem/bark of this plant is ethnomedicinally as contraceptive, astringent, diuretic, antiulcer, treatment for snake bites, rheumatism, small pox, skin diseases, hepatitis, leprosy, antitumor, bronchial asthma, antibacterial, gastroprotective, aphrodisiac, boils and abscesses [3,4]. The pharmacological studies have also reported the antimicrobial [5], antiulcer [6], anti-nociceptive [7], anti-inflammatory [3], anticancer [3] and antioxidant [8] activities of different leaf and bark extracts of A. officinalis. However, no studies have been done to assess the antidiabetic activities of this plant. Therefore, in the present study, the antidiabetic and antioxidant activities of leaf extracts were evaluated employing in vitro assay methods.

\section{Materials and Methods}

\section{Chemicals}

p-Nitrophenyl- $\alpha$-D-glucopyranoside (pNPG), Folin-Ciocalteu's Phenol reagent (FCP), catechol, catechin, EDTA, Nitro Blue Tetrazolium (NBT), hydroxylamine hydrochloride, sodium potassium tartrate, 3,5-dinitrosalicylic acid (DNS), sodium hydroxide, hydrogen peroxide, 1,1-diphenyl-2-picrylhydrazyl (DPPH), Butylated Hydroxy Toluene (BHT) and $\alpha$-glucosidase, $\alpha$-amylase were purchased from SRL
India, Ltd. Acarbose was purchased from Sigma Aldrich India. All the chemicals and reagents used in the study were of analytical grade.

\section{Collection of plant and preparation of extracts}

The leaf sample of Avicennia officinalis were collected from the Mahanadi delta region of Odisha coast. The specimen was identified by Prasanna Kumar Nayak, ICZMP, Forest Department, Govt. of Odisha. The leaf samples of $A$. officinalis were air dried in shade for 10 days, cut into pieces and were grinded but not to fine powder. For extraction, $10 \mathrm{~g}$ of dried sample was taken and mixed with petroleum ether and distilled water and shaken at room temperature for $72 \mathrm{~h}$ (separately carried out) to obtain Petroleum Ether Extracts (PEL) and Aqueous Extracts (AQL). The filtered liquid obtained was concentrated under reduced pressure in rotary evaporator. The obtained crude extract was stored in airtight container in refrigerator below $4^{\circ} \mathrm{C}$ for further studies.

\section{Antidiabetic assay}

$\boldsymbol{\alpha}$-amylase inhibition assay: $\alpha$-amylase inhibitory assay was carried out using the method described by Ali et al. [9]. To each of the test tube, $100 \mu \mathrm{l}$ crude plant extract of $1,0.5$ and $0.1 \mathrm{mg} / \mathrm{ml}$ conc. was added. Then $100 \mu \mathrm{l}$ distilled water followed by $100 \mu \mathrm{l}$ enzyme ( 4 units $/ \mathrm{ml} \alpha$-amylase) was added and mixed. This reaction was carried out at $25^{\circ} \mathrm{C}$ for $5 \mathrm{~min}$ followed by addition of $200 \mu \mathrm{l}$ starch (0.5\%). It was again re-incubated at $25^{\circ} \mathrm{C}$ for $5 \mathrm{~min}$. For terminating the reaction $200 \mu \mathrm{l}$ DNS (Dinitro

*Corresponding author: Hrudayanath Thatoi, Department of Biotechnology, North Orissa University, Sriram Chandra Vihar, Takatpur, Baripada, Odisha, India, Tel: +91 6742386075; E-mail: hn_thatoi@rediffmail.com

Received May 26, 2017; Accepted June 26, 2017; Published July 03, 2017

Citation: Das SK, Samantaray D, Thatoi H (2017) Evaluation of In Vitro Antidiabetic and Antioxidant Activities and Preliminary Phytochemical Screening of Leaf Extracts of Avicennia officinalis. J Bioanal Biomed 9: 173-176. doi:10.4172/1948 593X.1000174

Copyright: (c) 2017 Das SK, et al. This is an open-access article distributed under the terms of the Creative Commons Attribution License, which permits unrestricted use, distribution, and reproduction in any medium, provided the original author and source are credited. 
Salicylic Acid) was added and incubated in water bath at $85^{\circ} \mathrm{C}$ for 15 min. After incubation the mixture was diluted with $1800 \mu \mathrm{l}$ distilled water. The $\alpha$-amylase inhibitory activity was determined by measuring absorbance at $540 \mathrm{~nm}$ using UV-vis spectrophotometer.

a-glucosidase inhibition assay: $\alpha$-glucosidase inhibitory assay was carried out using the method developed by Apostolidis et al. [10] with slight modification. $50 \mu \mathrm{l}$ crude plant extract of $1,0.5$ and $0.1 \mathrm{mg} / \mathrm{ml}$ conc. was added. Then $125 \mu \mathrm{l}$ of enzyme solution ( 1 units/ $\mathrm{ml} \alpha$-glucosidase) and $150 \mu \mathrm{l}$ of phosphate buffer (pH-6.9) was added and incubated at $37^{\circ} \mathrm{C}$ for $10 \mathrm{~min} .100 \mu \mathrm{l} \mathrm{PNPG}(3 \mathrm{mM})$ was added to start the reaction and the reaction was re-incubated at $37^{\circ} \mathrm{C}$ for 20 min and stopped by adding $2 \mathrm{ml}$ of $\mathrm{Na}_{2} \mathrm{CO}_{3}$. $\alpha$-glucosidase activity was determined by measuring the p-nitro phenol release from PNPG at 405 nm using UV-Vis spectrophotometer.

\section{Antioxidant assays}

DPPH scavenging assay: Free radical scavenging activity was determined by using DPPH (2,2-diphenyl-1-picrylhydrazyl), as described by Brand-Williams et al. [11] with slight modification. $2 \mathrm{ml}$ of DPPH solution ( $0.1 \mathrm{mM}$ DPPH dissolved in methanol), $50 \mu \mathrm{l}$ of the plant extract were added and $150 \mu \mathrm{D}$ DSSO were added. The reaction mixture was shaken and incubated in the dark at $37^{\circ} \mathrm{C}$ for $30 \mathrm{~min}$. The absorbance was read at $517 \mathrm{~nm}$ against methanol as a blank by using UV-VIS spectrophotometer.

Superoxide scavenging assay: The superoxide scavenging activity was assayed by following the method of Kono [12]. $50 \mu \mathrm{l}$ of plant extract, $1 \mathrm{ml} \mathrm{Na} \mathrm{CO}_{3}(50 \mathrm{mM}) 0.4 \mathrm{ml} \mathrm{NBT}$ and $0.2 \mathrm{ml}$ of EDTA were added. The reaction was initiated by adding $0.4 \mathrm{ml}$ of hydroxyl amine hydro chloride $(3 \mathrm{mM})$. Zero time absorbance was taken at $560 \mathrm{~nm}$ using spectrophotometer followed by recording the absorbance after 15 min at $25^{\circ} \mathrm{C}$. The control was simultaneous run without plant extract.

Hydrogen peroxide scavenging assay: The ability of the extracts to scavenge hydrogen peroxide $\left(\mathrm{H}_{2} \mathrm{O}_{2}\right)$ was determined by the reported method Rath et al. [13]. Hydrogen peroxide (43 mM) was prepared in phosphate buffered saline ( $\mathrm{pH}$ 7.4). Aliquots of standard or extract solutions $\left(3.4 \mathrm{~mL}\right.$ ) were added to $0.6 \mathrm{~mL}$ of $\mathrm{H}_{2} \mathrm{O}_{2}$ solution. The reaction mixture was incubated at room temperature for $10 \mathrm{~min}$, and the absorbance was determined at $230 \mathrm{~nm}$.

\section{Phytochemical analysis}

Petroleum ether and aqueous extracts of A. officinalis leaf were subjected to preliminary qualitative phytochemical analysis using standard procedure for identification of phytochemicals like terpenoids, glycosides, tannins, saponins, flavooids and phenols. Similarly, the quantitative phytochemical analysis was carried for total phenol, flavonoid and tannins [14].

\section{UV-vis spectral analysis}

All the extracts of $A$. officinalis plant, were scanned in the wavelength ranging from $240-700 \mathrm{~nm}$ by using UV-VIS spectrophotometer and the characteristic peaks were detected for presence of phenolic compounds.

\section{Statistical analysis}

All experiments were conducted in triplicate and the data obtained were expressed as mean $\pm \mathrm{SD}$. The $\mathrm{IC}_{50}$ values were estimated by linear curve-fitting method.

\section{Results and Discussion}

As part of our continuous interest in the research of biological activities and chemical composition of different mangrove plants, this article reports for the first time the hypoglycaemic activity of leaf extracts of Avicennia officinalis via the inhibition of $\alpha$-amylase and $\alpha$ glucosidase enzymes along with its antioxidant properties.

\section{In vitro antidiabetic activity}

The present study has endeavoured to investigate the possible inhibitory effect of A. officinalis to modulate key enzymes involved in diabetes i.e., $\alpha$-amylase and $\alpha$-glucosidase. The inhibitory activity of crude petroleum ether and aqueous leaf extracts of A. officinalis against both the enzymes were carried out. The potential to inhibit the $a$-amylase and $\alpha$-glucosidase enzymes of the PEL and AQL were carried out at $0.1,0.5$ and $1 \mathrm{mg} / \mathrm{ml}$. The results showed that both PEL and AQL inhibit the enzymes in a dose dependent manner (Table 1). However, the AQL showed better $\alpha$-amylase and $\alpha$-glucosidase enzyme inhibition capacity in comparison to PEL. However, the $\mathrm{IC}_{50}$ value of $\mathrm{AQL}$ for both the assays was $>1 \mathrm{mg} / \mathrm{ml}$.

\section{In vitro antioxidant activity}

It has been well established that antioxidant activity plays a major role in the treatment of diabetes mellitus [15]. Many plants have been reported to possess both antidiabetics as well as antioxidant activity. Therefore, in the present study the antioxidant activity of the $A$. officinalis was investigated using the DPPH, super oxide and hydrogen peroxide scavenging method. The antioxidant potential of PEL and AQL were evaluated at $0.05,0.1$ and $0.15 \mathrm{mg} / \mathrm{ml}$ concentrations. Decreases in absorbance of the DPPH radical caused by the antioxidant were attributable to radical scavenging by hydrogen donation. The reaction was visible as a colour change from purple to yellow. The DPPH scavenging assay showed that the PEL possess better scavenging potential than AQL. The maximum DPPH scavenging was reported as $28.7 \%$ at $0.15 \mathrm{mg} / \mathrm{ml}$ for PEL (Table 2). The $\mathrm{IC}_{50}$ values for DPPH scavenging activities of PEL and AQL were reported as 0.25 and $0.43 \mathrm{mg} / \mathrm{ml}$. The present finding also corroborated the earlier study of Ravindran et al. [16] that reported the DPPH radical scavenging potential of methanol leaf extracts of $A$. officinalis with the $\mathrm{EC}_{50}$ value of $0.239 \mathrm{mg} / \mathrm{ml}$.

The superoxide scavenging activity is based on capacity of the antioxidants to decrease the absorbance of the chromophoric substance diformazan which is formed due to reduction of Nitro Blue Tetrazolium (NBT) by superoxide radicals generated by hydroxylamine hydrochloride [12]. The superoxide scavenging assay reported that the AQL could scavenge superoxide radicals more efficiently as compared to PEL. Highest superoxide scavenging activity was recorded as $27.7 \%$ at $0.15 \mathrm{mg} / \mathrm{ml}$ concentration for AQL and the $\mathrm{IC}_{50}$ values for $\mathrm{AQL}$ and PEL 0.27 and $0.44 \mathrm{mg} / \mathrm{ml}$ respectively.

Hydrogen peroxide is a weak oxidizing agent and can inactivates a number of enzymes by oxidation of thiol (-SH) groups, and also by forming hydroxyl radicals [17]. Hydrogen peroxide scavenging capacity of an extract is directly related to its antioxidant activity. The present study indicated maximum effect of $A$. officinalis in AQL extract and minimum in PEL, and the concentration of $0.15 \mathrm{mg} / \mathrm{ml}$ showed best result compared to other concentrations. Maximum hydrogen peroxide was observed as $39.9 \%$ in AQL at $0.15 \mathrm{mg} / \mathrm{ml}$. The $\mathrm{IC}_{50}$ value for AQL and PEL were recorded as 0.17 and $0.48 \mathrm{mg} / \mathrm{ml}$ respectively. Earlier study also showed that the methanol leaf extracts of $A$. officinalis exhibited hydrogen peroxide scavenging activity with $\mathrm{IC}_{50}$ value of $0.378 \mathrm{mg} / \mathrm{ml}$ [16]. 
Citation: Das SK, Samantaray D, Thatoi H (2017) Evaluation of In Vitro Antidiabetic and Antioxidant Activities and Preliminary Phytochemical Screening of Leaf Extracts of Avicennia officinalis. J Bioanal Biomed 9: 173-176. doi:10.4172/1948-593X.1000174

\section{Phytochemical analysis}

Phenolic compounds, such as flavonoids, phenolic acid and tannins possess diverse biological activities, such as anti-inflammatory, anticarcinogenic, antidiabetic and anti-atherosclerotic activities which might be related to their antioxidant activity [18]. Phytochemicals from plants are known to be good natural antioxidants and therefore in the present study, different phytochemicals from PEL and AQL in A. officinalis were analyzed by both qualitative and quantitative phytochemical assays. The qualitative phytochemical analysis showed the presence of steroids, saponins, phenols, terpenoids, tannins and flavonoids in both PEL and AQL extracts of A. officinalis. The quantitative phytochemical analysis showed presence of phenol, flavonoid and tannin in different quantities in PEL and AQL. The AQL recorded higher amount of total phenol content (12.8 mg Gallic Acid Equivalent (GAE)/g of dry sample), total tannin (3.31 mg Gallic Acid Equivalent (GAE)/g of dry sample), but higher amount of flavonoid was recorded in PEL (3.92 $\mu$ g Quercetin Equivalent (QE)/g of dry sample). The present study also corroborated with earlier findings of where crude ethanol and aqueous leaf extracts of $A$. officinalis showed presence of higher amount of phenols (Tables 3 and 4) [4].

The UV-Visible profile of the PEL and AQL of A. officinalis was studied at a wave length range of 200-700 nm (Figures 1 and 2). The profile showed the peaks at $270 \mathrm{~nm}$ confirming the presence of phenolic derivatives in the leaf extracts.

\section{Conclusion}

In this study, using various in vitro assay methods, the antidiabetic potential of petroleum ether and aqueous extracts of $A$. officinalis were evaluated based on the basis of their capacity to inhibit carbohydrate metabolizing enzymes like $a$-amylase and $a$-glucosidase. The antioxidant potential was also evaluated by studying DPPH, superoxide, and hydrogen peroxide scavenging activities. In addition, we further

\begin{tabular}{|c|c|c|c|c|}
\hline \multirow{2}{*}{ Concentration } & \multicolumn{2}{|c|}{$\%$ of $\alpha$-Amylase inhibition } & \multicolumn{2}{c|}{ \% of $\alpha$-Glucosidase inhibition } \\
\cline { 2 - 4 } & PEL & $10.5 \pm 0.02$ & $23.2 \pm 0.01$ & $10.0 \pm 0.01$ \\
\hline $\mathbf{0 . 1} \mathrm{mg} / \mathrm{ml}$ & $13.0 \pm 0.03$ & $27.7 \pm 0.01$ & $13.2 \pm 0.01$ \\
\hline $\mathbf{0 . 5} \mathrm{mg} / \mathrm{ml}$ & $17.4 \pm 0.01$ & $32.0 \pm 0.01$ & $17.4 \pm 0.01$ & $22.1 \pm 0.01$ \\
\hline $\mathbf{1 . 0} \mathrm{mg} / \mathrm{ml}$ & $>1.0 \mathrm{mg} / \mathrm{ml}$ & $>1.0 \mathrm{mg} / \mathrm{ml}$ & $>1.0 \mathrm{mg} / \mathrm{ml}$ \\
\hline
\end{tabular}

Table 1: Antidiabetic activities of leaf extracts of Avicennia officinalis. Data are expressed as mean $\pm S D(n=3)$.

\begin{tabular}{|c|c|c|c|c|c|c|}
\hline \multirow{2}{*}{ Concentration } & \multicolumn{2}{|c|}{$\%$ of DPPH scavenging } & \multicolumn{2}{|c|}{$\%$ of Superoxide scavenging } & \multicolumn{2}{|c|}{$\%$ of $\mathrm{H}_{2} \mathrm{O}_{2}$ scavenging } \\
\hline & PEL & AQL & PEL & AQL & PEL & AQL \\
\hline $0.05 \mathrm{mg} / \mathrm{ml}$ & $18.9 \pm 0.71$ & $12.7 \pm 0.50$ & 7.6 & $16.7 \pm 0.02$ & $7.9 \pm 0.02$ & $30.9 \pm 0.02$ \\
\hline $0.1 \mathrm{mg} / \mathrm{ml}$ & $23.7 \pm 1.81$ & $15.2 \pm 0.40$ & $12.1 \pm 0.01$ & $21.2 \pm 0.01$ & $10.6 \pm 0.38$ & $34.6 \pm 0.09$ \\
\hline $0.15 \mathrm{mg} / \mathrm{ml}$ & $28.7 \pm 1.62$ & $17.5 \pm 1.11$ & $16.9 \pm 0.01$ & 27.7 & $16.2 \pm 1.06$ & $39.9 \pm 0.86$ \\
\hline $\mathrm{IC}_{50} \mathrm{mg} / \mathrm{ml}$ & 0.25 & 0.43 & 0.44 & 0.27 & 0.48 & 0.17 \\
\hline
\end{tabular}

Table 2: Antioxidant activities of leaf extracts of Avicennia officinalis. Data are expressed as mean \pm SD $(n=3)$.

\begin{tabular}{|c|c|c|c|c|c|}
\hline Sample & Steroids & Saponins & Phenols & Terpenoids & Flavonoids \\
\hline PEL & + & + & + & + \\
\hline AQL & + & + & + & + \\
\hline
\end{tabular}

Table 3: Preliminary phytochemical screening of all the extracts of Avicennia officinalis. Data are expressed as mean \pm SD ( $n=3$ ).

\begin{tabular}{|c|c|c|c|}
\hline Sample & Total Phenol $(\mathbf{m g} / \mathbf{g})$ & Total Flavonoid $(\boldsymbol{\mu g} / \mathbf{g})$ & Total tannin $(\mathbf{m g} / \mathbf{g})$ \\
\hline PEL & 10.46 & 2.17 & 3.92 \\
\hline AQL & 12.80 & 3.49 \\
\hline
\end{tabular}

Table 4: Quantitative phytochemical assay of all the extracts of Avicennia officinalis.

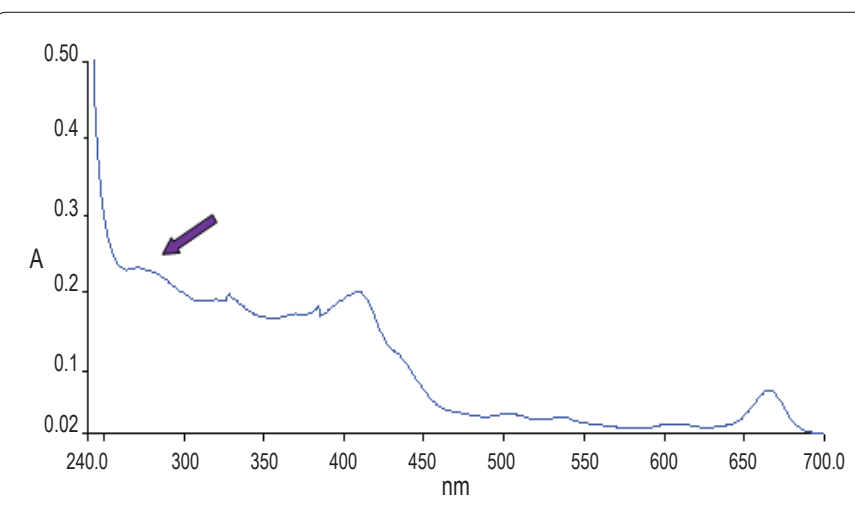

Figure 1: UV-vis spectral analysis of Avicennia officinalis petroleum ether leaf extracts.

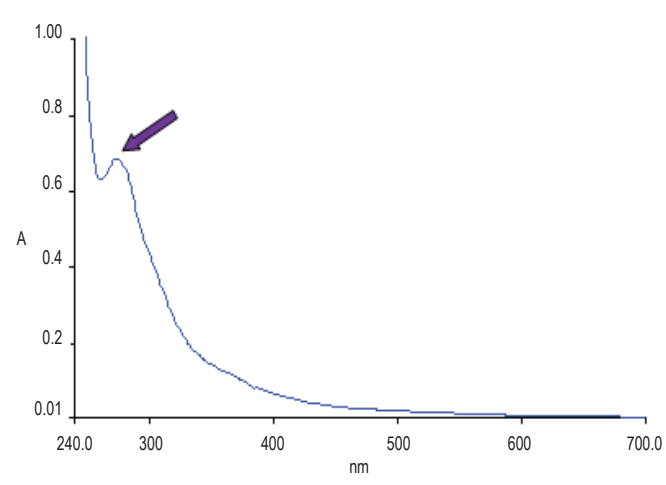

Figure 2: UV-vis spectral analysis of Avicennia officinalis aqueous leaf extracts. 
Citation: Das SK, Samantaray D, Thatoi H (2017) Evaluation of In Vitro Antidiabetic and Antioxidant Activities and Preliminary Phytochemical Screening of Leaf Extracts of Avicennia officinalis. J Bioanal Biomed 9: 173-176. doi:10.4172/1948-593X.1000174

evaluated the presence of different phytochemicals both qualitatively and quantitatively. The results clearly confirmed the antidiabetic and radical scavenging effect of the $A$. officinalis leaves extracts. Therefore, this mangrove plant merits further exploration both chemically and biologically to exploit its relevant therapeutic effect.

\section{Acknowledgements}

The authors are thankful to PCCF (Wildlife), Govt of Odisha, for giving the necessary permission for the research work. The authors are also thankful to the DFO, Rajnagar, Odisha and their field staff for their kind help and cooperation during the field study.

\section{Authors' Contributions}

S. K. Das, D. Samantaray have conducted all the experiments. H. N. Thatoi has edited the manuscript.

\section{References}

1. Das SK, Patra JK, Thatoi HN (2015) Antioxidative response to abiotic and biotic stresses in mangrove plants: A review. Int Rev Hydrobiol 100: 1-17.

2. https://www.theplantlist.org

3. Sumithra M, Anbu J, Nithya S, Ravichandiran V (2011) Anticancer activity of methanolic leaves extract of Avicennia offcinalis on ehrlich ascitis carcinoma cell lines in rodents. Int J Pharm Tech Res 3: 1290-1292.

4. Thirunavukkarasu $P$, Ramanathan $T$, Ramkumar L, Shanmugapriya $R$, Renugadevi G (2011) The antioxidant and free radical scavenging effect of Avicennia offcinalis. J Med Plants Res 5: 4754-4758.

5. Bakshi M, Chaudhuri $P$ (2014) Antimicrobial potential of leaf extracts of ten mangrove species from Indian Sundarban. Int J Pharm Biol Sci 5: 294-304.

6. Thirunavukkarasu P, Ramanathan T, Ramkumar L, Shanmugapriya R (2010) Antiulcer effect of Avicennia offcinalis leaves in Albino rats. WASJ 9: 55-58.

7. Shahid IZ, Ahmed F, Karmakar D, Sadhu SK (2007) Anti-nociceptive activity of Avicennia offcinalis. Orient Pharm Exp Med 7: 100-102.
8. Sharief MN, Srinivasulu A, Satyaveni P, Umamaheswararao V (2014) Evaluation of antioxidant activity in fruit extracts of Avicennia marina L. and Avicennia offcinalis L. Int J Pharm 4: 149-153.

9. Ali H, Houghton PJ, Soumyanath A (2006) a-amylase inhibitory activity of some Malaysian plants used to treat diabetes; with particular reference to Phyllanthus amarus. J Ethnopharmacol 107: 449-455.

10. Apostolidis E, Kwon Y, Shetty K (2007) Inhibitory potential of herb, fruit, and fungal-enriched cheese against key enzymes linked to type 2 diabetes and hypertension. Innov Food Sci Emerg Technol 8: 46-54.

11. Brand-Williams W, Cuvelier ME, Berset C (1995) Use of free radical method to evaluate antioxidant activity. LWT-Food Sci Technol 28: 25-30.

12. Kono Y (1978) Generation of superoxide radical during autoxidation of hydroxylamine and an assay for superoxide dismutase. Arch Biochem Biophys 186: 189-195.

13. Rath S, Patra JK, Mohapatra N, Mohanty G, Dutta S, et al. (2011) In vitro antibacterial and antioxidant studies of Croton roxburghii L., from Similipal Biosphere Reserve. Indian J Microbiol 51: 363-368.

14. Harborne AJ (1998) Phytochemical methods: a guide to modern techniques of plant analysis. Springer: London.

15. Raphael KR, Sabu MC, Khuttan R (2002) Hypoglycemic effect of methanol extract of Phyllanthus amarus Schum \& Thonn on alloxan induced diabetes mellitus in rats and its relaxation with antioxidant potential. Indian J Exp Biol 40: 905-909.

16. Ravindran C, Naveenan T, Varatharajan GR, Rajasabapathy R, Meena RM (2012) Antioxidants in mangrove plants and endophytic fungal associations. Bot Mar 55: 269-279

17. Miller MJ, Sadowska-Krowicka H, Chotinaruemol S, Kakkis JL, Clark DA (1993) Amelioration of chronic ileitis by nitric oxide synthase inhibition. J Pharm Exp Ther 264: 11-16.

18. Chung KT, Wong TY, Huang Y (1998) Tannins and human health: A review. Crit Rev Food Sci Nutr 38: 421-464. 